BAREKENG: Jurnal Ilmu Matematika dan Terapan

March $2021 \quad$ Vol. 15 No. 1 Page 137-146

P-ISSN: 1978-7227 E-ISSN: 2615-3017

doi : https://doi.org/10.30598/barekengvol15iss1pp137-146

\title{
PENDEKATAN ANALISIS DISKRIMINAN PADA PEMBELAJARAN DARING DI MASA PANDEMI COVID-19
}

\section{Discriminant Analysis Approach To Online Learning In COVID-19 Pandemic}

\author{
Cindy Cahyaning Astuti ${ }^{*}$, Akbar Wiguna ${ }^{2}$, Novia Ariyanti ${ }^{3}$ \\ 1,2 Jurusan Pend. Teknologi Informasi, Fakultas Psikologi dan Ilmu Pendidikan, Univeritas Muhammadiyah Sidoarjo \\ ${ }^{3}$ Jurusan Informatika, Fakultas Sains dan Teknologi, Univeritas Muhammadiyah Sidoarjo \\ Jln. Majapahit 666B Sidoarjo, Jawa Timur, Indonesia \\ Corresponding author e-mail: ${ }^{1 *}$ cindy.cahyaning@ umsida.ac.id
}

\begin{abstract}
Abstrak
Pembelajaran dalam jaringan (daring) adalah salah satu solusi yang dapat diterapkan di tengah pandemi COVID-19. Sejak pandemi COVID-19 terjadi proses perkuliahan di UMSIDA menggunakan pembelajaran daring $100 \%$ dengan media e-learning UMSIDA. Melalui e-learning,mahasiswa UMSIDA dapat melaksanakan Pembelajaran Jarak Jauh (PJJ) tanpa bertemu dengan dosen secara langsung. Sejauh ini belum dilakukan penelitian terkait kesiapan mahasiswa dalam mengikuti pembelajaran daring dimasa pandemi COVID-19. Berdasarkan hal tersebut pada penelitian ini fokus untuk mengetahui kesiapan mahasiswa dalam mengikuti perkuliahan daring dimasa pandemi COVID-19 menggunakan analisis diskriminan. Berdasarkan hasil analisis, variabel prediktor yang menjadi pembeda terkuat adalah fleksibilitas waktu kuliah $\left(\mathrm{X}_{1}\right)$ karena merupakan variabel dengan koefisien terbesar. Hal ini berarti bahwa variabel fleksibilitas waktu kuliah $\left(\mathrm{X}_{1}\right)$ mempunyai daya pemisah terkuat terhadap kesiapan pembelajaran daring di masa pandemi COVID19. Selain itu berdasarkan hasil penelitian juga diketahui bahwa menurut perspektif mahasiswa, media pembelajaran yang paling memudahkan interaksi dengan dosen dan media pembelajaran yang paling memudahkan dalam memahami materi adalah menggunakan video conference (Zoom, Google Meet, dsb). Disisi lain pilihan sistem pembelajaran yang paling dipilih oleh mahasiswa saat pandemi COVID-19 berakhir adalah sistem daring 30\% dan luring $70 \%$.
\end{abstract}

Kata Kunci : E-Learning, Diskriminan, Pandemi COVID-19

\begin{abstract}
Online learning is solution that implemented in the midst of the COVID-19 pandemic. Since COVID-19 pandemic, the learning process at UMSIDA used 100\% online learning with UMSIDA e-learning media.It can accommodate students to carry out distance learning. So far, research has not been carried out readiness of students to take part in online learning during the COVID-19 pandemic. Based on this, this research focuses on knowing the readiness of students to take online lectures during the COVID-19 pandemic using discriminant analysis. Based on the results of the analysis of the predictor variable, the strongest differentiator is the flexibility of lecture time (X1) because the variable with the largest coefficient. This means that the variable time flexibility (XI) has the strongest dividing power against online learning readiness during the COVID-19 pandemic. In addition, it also known that according to the student's perspective, the learning media that makes interaction with lecturers the most easy and the learning media that makes it the most easy to understand the material is using video conferencing (Zoom, Google Meet, etc.). On the other hand, choice of the learning system most chosen by students when the COVID-19 pandemic ends is online system 30\% and offline $70 \%$.
\end{abstract}

Keywords: E-Learning, Discriminant, COVID-19 Pandemic

Article info:

Received: $21^{\text {st }}$ January 2021 Accepted: $25^{\text {th }}$ Februari 2021

How to cite this article:

C. C. Astuti, A. Wiguna, N. Ariyanti, "PENDEKATAN ANALISIS DISKRIMINAN PADA PEMBELAJARAN DARING DI MASAPANDEMI COVID-19”, BAREKENG: J. Il. Mat. \& Ter., vol. 15, no. 1, pp. 137-146, Mar. 2021.

This work is licensed under a Creative Commons Attribution-ShareAlike 4.0 International License. Copyright $@ 2021$ Cindy Cahyaning Astuti, Akbar Wiguna, Novia Ariyanti 


\section{PENDAHULUAN}

Pembelajaran dalam jaringan atau lebih dikenal dengan istilah daring adalah solusi yang dapat diterapkan pada masa Pandemi COVID-19. Pembelajaran daring yang dikembangakan oleh beberapa Universitas adalah pembelajaran daring dengan media e-learning. E-learning dapat didefinisikan sebagai bentuk pembelajaran tidak langsung atau jarak jauh yang menggunakan teknologi komputer dan internet. $E$ learning atau internet enabled learning merupakan suatu wadah yang berisikan ilmu pengetahuan yang menggabungkan metode pembelajaran dan media elektronik. Pembelajaran menggunakan e-learning memfokuskan pada peserta didik, karena pelajar diarahkan untuk lebih mandiri dengan mempelajari materi pembelajaran dalam E-learning. E-learning menuntut pelajar untuk lebih aktif dalam kegiatan pembelajaran. E-learning juga dapat dikataan suatu lingkungan belajar yang terbuka dan menyebar menggunakan internet dan teknologi berbasis web. Berdasarkan tipe, e-learning dibagi mnejadi dua yaitu: Synchronous dan Asynchronous. Tipe Synchronous memiliki arti di waktu bersamaan, yang memiliki arti bahwa pembelajaran yang dilakukan secara berrsamaan ketika pengajar sedang mengajar dan siswa sedang belajar. Sedangkan tipe Asynchronous yaitu tidak diwaktu bersamaan, yaitu seseorang mengambil pelajaran di waktu berbeda dengan pengajar saat memberikan pembelajaran [1].

Sejak tahun 2017, Universitas Muhammadiyah Sidoarjo (UMSIDA) telah menggunakan e-learning berbasis moodle untuk menerapkan system pembelajaran daring. Sebelum terjadinya pandemi COVID-19 $e$ learning UMSIDA diterapkan pada 4 pertemuan perkuliahan dari total 16 pertemuan dalam satu semester. Pada pertengahan maret 2020, sejak pandemi COVID-19 terjadi proses perkuliahan di UMSIDA menggunakan pembelajaran daring $100 \%$ dengan media e-learning UMSIDA tersebut. Ditengah pandemi COVID-19 yang melanda Indonesia e-learning menjadi sebuah solusi media pembelajaran. Melalui $e$ learning yang telah dirancang UMSIDA dapat mengakomodasi mahasiswa untuk melaksanakan Pembelajaran Jarak Jauh (PJJ) tanpa bertemu dengan dosen secara langsung. Fitur-fitur yang tersedia di Elearning umsida sudah sangat lengkap yang dapat memudahkan dosen sebagai pengajar serta mahasiswa dalam mengikuti pembelajaran daring. Pembelajaran daring menggunakan e-learning UMSIDA selama pandemi COVID-19 dilakukan sejak pertengahan maret 2020 sampai akhir perkuliahan semester genap tahun akademik 2019/2020. Pada tahun ajaran baru yaitu semester ganjil 2020/2021 sistem perkuliahan di UMSIDA masih menggunakan system daring 100\% sesuai dengan kebijakan pemerintah karena sampai awal September 2020 kasus terkonfirmasi COVID-19 juga belum mengalami penurunan sehingga tidak dimungkinkan untuk melaksanakan pembelajaran tatap muka dalam waktu dekat. E-learning memiliki karakteristik yang berbeda dengan pembelajaran konvensional, karakteristik e-learning antara yaitu interaktivitas, kemandirian, aksesibilitas dan pengayaan. Interaktivitas dapat didefinisikan dengan tersedianya sarana komunikasi yang beragam, secara langsung (Synchronous) yaitu chatting maupun secara tidak langsung (Asnchronous) seperti forum. Kemandirian dapat didefinisikan dengan flesibilitas dalam mengatur waktu, tempat pengajaran, dan bahan untuk mengajar. Aksesibilitas dapat didefinisikan dengan pendistribusian sumber bahan belajar yang disalurkan menggunakan bantuan internet. Pengayaan dapat didefinisikan dengan penyampaian presentasi dan kegiatan pembelajaran semain mudah dengan menggunakan bantuak teknologi informasi, seperti video, simulasi, animasi, dan streaming.E-learning juga memiliki beberapa kelebihan dibandingkan dengan media pembelajaran yang lain antara lain adalah (a) Adanya fasilitas e-moderating yang memudahkan komunikasi antara guru dan siswa tanpa ada batas jarak, tempat, dak waktu; (b) Dengan menggunakan internet maka pengajar dan peserta didik dapat melihat jadwal yang tertata rapi tanpa harus bertatap muka; (c) Peserta didik dapat mengulang lagi materi yang diberikan dimana pun berada; (d) Pengajar dan peserta didik dapat berdiskusi melalui internet dengan tidak ada batasan peserta didik yang bergabung; (e)Adanya perubahan sikap peserta didik dari pasif mejadi aktif dengan melatih kemadirian pada peserta didik [2].

Beberapa penelitian terdahulu yang relevan tentang pembelajaran daring telah dilakukan antara lain oleh Sadikin dan Hamidah (2020) hasil penelitian menunjukkan bahwa mahasiswa telah memiliki fasilitasfasilitas dasar yang dibutuhkan untuk mengikuti pembelajaran daring, pembelajaran daring memiliki fleksibilitas dalam pelaksanaan dan mampu mendorong munculnya kemandirian belajar dan motivasi untuk lebih aktif dalam belajar, Selain itu pembelajaran jarak jauh juga meminimalisir munculnya keramaian mahasiswa sehingga dianggap dapat mengurangi potensi penyebaran COVID-19 [3]. Hasil penelitian oleh Handarini dan Wulandari (2020), menunjukkan salah satu solusi untuk menerapkan protokol kesehatan menjaga jarak aman (social distancing) guna mencegah mata rantai penyebaran wabah COVID-19 adalah dengan menggunakan pembelajaran daring [4]. Hasil penelitian oleh Putria et.al (2020) menunjukkan bahwa pandemi COVID-19 membawa dampak yang sangat besar terhadap proses pembelajaran. Pembelajaran daring yang dilakukan untuk anak usia sekolah dasar dirasa kurang efektif. Ada beberapa faktor pendukung 
guru dalam proses pembelajaran daring yaitu ketersediannya handphone, kuota dan jaringan internet yang stabil [5]. Hasil penelitian lain oleh Dewi (2020) menunjukkan bahwa dampak COVID-19 terhadap implementasi pembelajaran daring di sekolah dasar dapat terlaksanakan dengan cukup baik apabila adanya kerjasama antara guru, siswa dan orang tua dalam belajar di rumah [6].

Terdapat beberapa kendala baik kendala teknis dan kendala non teknis yang dialami oleh dosen maupun mahasiswa dalam pembelajaran 100\% daring yang dilakukan UMSIDA sejak pandemi COVID-19 terjadi. Salah satunya adalah kendala jaringan internet yang kurang stabil baik yg dialami dosen atau mahasiswa. Jaringan internet adalah kebutuhan utama saat kita melakukan pembelajaran dengan sistem dalam jaringan atau lebih dikenal dengan sistem daring. Jangkauan jaringan internet yang berbeda-beda pada setiap daerah tentu menjadi kendala tersendiri saat system pembelajaran daring dilakukan. Salah satu solusi yang dilakukan UMSIDA adalah memberikan subsidi paket internet yang diberikan baik pada dosen dan mahasiswa, diharapkan dengan adanya subsidi paket internet tersebut dapat membantu mahasiswa dalam mengikuti pembelajaran daring. Inovasi dan pelatihan juga selalu dilakukan UMSIDA secara berkala pada dosen untuk menyempurnakan kegiatan pembelajaran daring yang dilakukan. Namun sejauh ini belum dilakukan penelitian terkait kesiapan mahasiswa dalam mengikuti pembelajaran daring di masa pandemi COVID-19. Kesiapan mahasiswa dinilai dari perkuliahan daring yang telah dijalani oleh mahasiswa sejak pandemi COVID-19 terjadi yaitu pada semester genap tahun ajaran 2019/2020 sedangkan kesiapan mahasiswa dilihat pada kesiapan mahasiswa tersebut dalam mengikuti perkuliahan daring di semester selanjutnya yaitu semester ganjil tahun ajaran 2020/2021. Berdasarkan hal tersebut maka penelitian ini akan bertujuan untuk mengetahui kesiapan mahasiswa dalam mengikuti perkuliahan daring di masa pandemi COVID-19 menggunakan analisis diskriminan.

\section{METODE PENELITIAN}

Pada penelitian ini metode analisis yang digunakan adalah analisis diskriminan. Pada umumnya metode analisis diskriminan diawali dengan pengujian asumsi pada data yang digunakan dalam proses analisis. Selanjutnya dilakukan proses klasifikasi menggunakan analisis diskriminan.

\subsection{Analisis Diskriminan}

Analisis diskriminan adalah salah satu analisis multivariat yang dapat digunakan untuk memodelkan hubungan antara variabel respon dengan jenis skala data kategorik (nominal atau ordinal dan bersifat kualitatif) dengan satu atau lebih variabel prediktor dengan jenis data kuantitatif [7]. Analisis diskriminan digunakan untuk mengklasifikasikan suatu individu atau observasi ke dalam kelompok yang saling bebas (mutually exclusive) dan menyeluruh berdasarkan variabel prediktor yang digunakan [8]. Analisis diskriminan pada umumnya mirip dengan regresi linier berganda. Sama seperti regresi linier berganda, dalam analisis diskriminan menggunakan satu variabel respon dan lebih dari satu variabel preditor. Letak perbedaan analisis diskriminan dengan analisis regresi linier berganda adalah pada jenis variabel respon yang digunakan. Pada analisis diskriminan variabel respon yang digunakan adalah jenis skala data kualitatif, sedangkan dalam regresi linier berganda variabel respon digunakan adalah jenis skala data kuantitatif [9].

Pada dasarnya analisis diskriminan dilakukan dengan menggunakan pendekatan matriks varian kovarian dalam kelompok dan matriks varian kovarian antar kelompok. Fungsi diskriminan dibentuk sedemikian rupa sehingga dengan menggunakan skor diskriminan maka keragaman relatif antar kelompok terhadap keragaman dalam kelompok menjadi maksimal [10]. Fungsi diskriminan didefinisikan sebagai kombinasi linier terbobot dari variabel pembeda yang memaksimalkan keragaman relatif antar kelompok terhadap keragaman relatif dalam kelompok [11]. Hasil analisis diskriminan dapat digunakan untuk mengetahui perbedaan antar grup pada variabel respon, jika terdapat perbedaan dengan menggunakan analisis diskriminan dapat diketahui variabel prediktor manakah pada fungsi diskriminan yang membuat perbedaan tersebut [12]. Selain itu hasil analisis yaitu fungsi atau model diskriminan digunakan untuk melakukan klasifikasi terhadap obyek ke dalam suatu kelompok. Fungsi diskriminan yang terbentuk merupakan kombinasi linier dari variabel prediktor yang akan menghasilkan persaaan dalam pemisahan kelompokkelompok. Fungsi ini akan memberikan nilai-nilai yang sedekat mungkin dalam kelompok dan sejauh mungkin antar kelompok. Model analisis diskriminan adalah sebuah persamaan yang menunjukkan suatu kombinasi linier dari masing-masing variabel preditor yang digunakan [13]. 
Pada analisis diskriminan yang diestimasi adalah nilai koefisien sehingga nilai estimasi setiap grup berbeda. Hal ini terjadi pada saat rasio jumlah kuadrat antar grup terhadap jumlah kuadrat dalam grup) untuk skor diskriminan mencapai maksimum. Berdasarkan nilai estmasi tersebut keanggotaan observasi dalam kelompok dapat diprediksi. Asumsi yang harus dipenuhi agar model diskriminan dapat digunakan antara lain adalah[14] :

a. Variabel prediktor harus berdistribusi normal (Normal Multivariat).

b. Matriks kovarians pada semua variabel prediktor relatif sama (equal).

c. Tidak terjadi multikolinearitas (tidak berkorelasi) antar variabel prediktor.

Untuk mengetahui kekuatan fungsi diskriminan yang telah terbentuk pada masing-masing observasi dalam proses pengelompokkan dapat dilakukan dengan melihat nilai dari korelasi kanonik, akar ciri (eigen value) dan group centroid:

\section{a. Korelasi Kanonik (Canonical correlation)}

Canonical Correlation (R) merupakan satuan ukuran hubungan keterkaitan antara kelompok yang terbentuk oleh variabel respon dengan fungsi diskriminan yang ada. Ketika nilai $\mathrm{R}$ adalah nol, maka dapat disimpulkan bahwa tidak ada hubungan antara kelompok yang ada dengan fungsi yang terbentuk. Sebaliknya apabila nilai $\mathrm{R}$ mendekati 1, menunjukkan bahwa terdapat korelasi yang tinggi antara fungsi diskriminan dengan kelompok yang ada. Nilai $\mathrm{R}$ digunakan untuk menjelaskan seberapa besar fungsi yang terbentuk berguna dalam menentukan perbedaan kelompok.

\section{b. Akar Ciri (Eigen Value)}

Nilai eigenvalue menunjukkan hubungan linier variabel prediktor atau disebut dengan multikolinearitas dalam fungsi diskriminan. Multikolinearitas akan terjadi bila eigen value mendekati 0 (nol).

\section{c. Group Centroid}

Group centroid dapat didefnisikan rata-rata nilai diskriminan dari observasi dalam sebuah kelompok. Semakin besar perbedaan pada group centroid antar kelompok, maka fungsi diskriminan yang akan diperoleh semakin membedakan kelompok yang ada. Tingkat akurasi pada proses pengelompokkan menentukan baik atau tidaknya suatu pengelompokkan. Persentase ketepatan pengelompokan dapat dihitung dari matrik klasifikasi yang menunjukkan nilai sebenarnya (actual members) dan nilai prediksi (prediction members) dari setiap kelompok [15].

\subsection{Variabel Penelitian}

Pada penelitian ini variabel penelitian yang digunakan ditunjukkan pada Tabel 1. sebagai berikut:

Tabel 1. Uraian Variabel Penelitian

\begin{tabular}{|c|c|c|}
\hline Variabel & Pernyataan & Indikator \\
\hline $\begin{array}{l}\text { Kesiapan mahasiswa } \\
\text { pembelajaran daring }(\mathrm{Y})\end{array}$ & $\begin{array}{l}\text { Saya merasa dalam pembelajaran } \\
\text { daring menggunakan E-Learning }\end{array}$ & $\begin{array}{l}1=\text { Tidak Siap } \\
2=\text { Siap }\end{array}$ \\
\hline Fleksibilitas waktu kuliah $\left(\mathrm{X}_{1}\right)$ & $\begin{array}{l}\text { Saya merasa dengan menggunakan } \\
\text { E-Learning waktu kuliah menjadi } \\
\text { lebih fleksibel }\end{array}$ & $\begin{array}{l}1=\text { Sangat Setuju } \\
2=\text { Setuju } \\
3=\text { Kurang Setuju } \\
4=\text { Tidak Setuju } \\
5=\text { Sangat Tidak Setuju }\end{array}$ \\
\hline Pemahaman materi $\left(\mathrm{X}_{2}\right)$ & $\begin{array}{l}\text { Saya merasa dengan E-Learning, } \\
\text { materi mejadi lebih mudah untuk } \\
\text { dipahami }\end{array}$ & $\begin{array}{l}1=\text { Sangat Setuju } \\
2=\text { Setuju } \\
3=\text { Kurang Setuju } \\
4=\text { Tidak Setuju } \\
5=\text { Sangat Tidak Setuju }\end{array}$ \\
\hline Kemudahan pengumpulan tugas $\left(\mathrm{X}_{3}\right)$ & $\begin{array}{l}\text { Saya merasa dengan } \text { E-Learning, } \\
\text { pengumpulan tugas jadi lebih } \\
\text { mudah }\end{array}$ & $\begin{array}{l}1=\text { Sangat Setuju } \\
2=\text { Setuju } \\
3=\text { Kurang Setuju } \\
4=\text { Tidak Setuju } \\
5=\text { Sangat Tidak Setuju }\end{array}$ \\
\hline
\end{tabular}




\begin{tabular}{|c|c|c|}
\hline Variabel & Pernyataan & Indikator \\
\hline $\begin{array}{lr}\text { Kemudahan interaksi } & \text { antara } \\
\text { mahasiswa dan dosen }\left(\mathrm{X}_{4}\right) & \end{array}$ & $\begin{array}{l}\text { Saya merasa dengan E-Learning, } \\
\text { interaksi dengan dosen menjadi } \\
\text { lebih mudah }\end{array}$ & $\begin{array}{l}1=\text { Sangat Setuju } \\
2=\text { Setuju } \\
3=\text { Kurang Setuju } \\
4=\text { Tidak Setuju } \\
5=\text { Sangat Tidak Setuju }\end{array}$ \\
\hline $\begin{array}{l}\text { Koneksi Internet pada saat mahasiswa } \\
\text { menggunakan e-learning }\left(\mathrm{X}_{5}\right)\end{array}$ & $\begin{array}{l}\text { Saya merasa koneksi internet yang } \\
\text { saya gunakan untuk kegiatan } \\
\text { belajar menggunakan E-Learning } \\
\text { sudah baik }\end{array}$ & $\begin{array}{l}1=\text { Sangat Setuju } \\
2=\text { Setuju } \\
3=\text { Kurang Setuju } \\
4=\text { Tidak Setuju } \\
5=\text { Sangat Tidak Setuju }\end{array}$ \\
\hline $\begin{array}{l}\text { Pemahaman mengakses e-learning } \\
\left(\mathrm{X}_{6}\right)\end{array}$ & $\begin{array}{l}\text { Saya merasa sudah paham untuk } \\
\text { mengakses E-Learning sebagai } \\
\text { media pembelajaran }\end{array}$ & $\begin{array}{l}1 \text { = Sangat Setuju } \\
2=\text { Setuju } \\
3=\text { Kurang Setuju } \\
4=\text { Tidak Setuju } \\
5=\text { Sangat Tidak Setuju }\end{array}$ \\
\hline $\begin{array}{l}\text { Prasarana pembelajaran e-learning } \\
\text { mahasiswa }\left(\mathrm{X}_{7}\right)\end{array}$ & $\begin{array}{l}\text { Saya merasa prasarana yang saya } \\
\text { miliki untuk pembelajara } E- \\
\text { learning seperti laptop dan } \\
\text { handphone sudah mumpuni }\end{array}$ & $\begin{array}{l}1=\text { Sangat Setuju } \\
2=\text { Setuju } \\
3=\text { Kurang Setuju } \\
4=\text { Tidak Setuju } \\
5=\text { Sangat Tidak Setuju }\end{array}$ \\
\hline
\end{tabular}

\section{HASIL DAN PEMBAHASAN}

\subsection{Pengujian Asumsi Analisis Diskriminan}

\subsubsection{Normal Multivariat}

Pada analisis diskriminan asumsi pertama yang harus terpenuhi adalah variabel prediktor berdistribusi normal. Pengujian distrbusi normal dilakukan pada semua variabel prediktor yaitu $\mathrm{X}_{1}, \mathrm{X}_{2}, \mathrm{X}_{3}$, $\mathrm{X}_{4}, \mathrm{X}_{5}, \mathrm{X}_{6}$ dan $\mathrm{X}_{7}$ menggunakan uji Kolmoggorov Smirnov. Hasil uji Kolmoggorov Smirnov pada semua variabel prediktor disajikan pada Tabel 2. sebagai berikut:

Tabel 2. Hasil Pengujian Kolmoggorov Smirnov

\begin{tabular}{ccccc}
\hline No. & Variabel & Statistik K-S & $\mathbf{d b}$ & P-value \\
\hline 1. & $\mathrm{X} 1$ & 0.160 & 385 & 0.000 \\
\hline 2. & $\mathrm{X} 2$ & 0.165 & 385 & 0.000 \\
\hline 3. & $\mathrm{X} 3$ & 0.185 & 385 & 0.000 \\
\hline 4. & $\mathrm{X} 4$ & 0.171 & 385 & 0.000 \\
\hline 5. & $\mathrm{X} 5$ & 0.150 & 385 & 0.000 \\
\hline 6. & $\mathrm{X} 6$ & 0.196 & 385 & 0.000 \\
\hline 7. & $\mathrm{X} 7$ & 0.159 & 385 & 0.000 \\
\hline
\end{tabular}

Berdasarkan nilai pada Tabel 2, diketahui bahwa p-value uji Kolmoggorov Smirnov semua variabel prediktor yaitu $\mathrm{X}_{1}, \mathrm{X}_{2}, \mathrm{X}_{3}, \mathrm{X}_{4}, \mathrm{X}_{5}, \mathrm{X}_{6}$ dan $\mathrm{X}_{7}$ lebih besar dari $\alpha(0.05)$, sehingga dapat disimpulkan bahwa semua variabel prediktor menyebar normal dan asumi normal multivariat terpenuhi.

\subsubsection{Matriks Kovarians Relatif Sama (Equal)}

Pada analisis diskriminan asumsi kedua yang harus terpenuhi adalah Matriks kovarians pada semua variabel prediktor relatif sama (equal). Pengujian dilakukan pada semua variabel prediktor yaitu $\mathrm{X}_{1}, \mathrm{X}_{2}, \mathrm{X}_{3}$, $\mathrm{X}_{4}, \mathrm{X}_{5}, \mathrm{X}_{6}$ dan $\mathrm{X}_{7}$ menggunakan p-value pada Tests of Equality of Group Means. Hasil pengujian matriks kovarians pada semua variabel prediktor disajikan pada Tabel 3, sebagai berikut: 
Tabel 3. Hasi Pengujian Matriks Kovarians

\begin{tabular}{ccc}
\hline No. & Variabel Prediktor & P-value \\
\hline 1. & $\mathrm{X}_{1}$ & 0.002 \\
\hline 2. & $\mathrm{X}_{2}$ & 0.000 \\
\hline 3. & $\mathrm{X}_{3}$ & 0.030 \\
\hline 4. & $\mathrm{X}_{4}$ & 0.000 \\
\hline 5. & $\mathrm{X}_{5}$ & 0.014 \\
\hline 6. & $\mathrm{X}_{6}$ & 0.000 \\
\hline 7. & $\mathrm{X}_{7}$ & 0.000 \\
\hline
\end{tabular}

Berdasarkan Tabel 3. diketahui bahwa $p$-value semua variabel prediktor yaitu $\mathrm{X}_{1}, \mathrm{X}_{2}, \mathrm{X}_{3}, \mathrm{X}_{4}, \mathrm{X}_{5}, \mathrm{X}_{6}$ dan $\mathrm{X}_{7}$ lebih kecil dari $\alpha(0.05)$, sehingga dapat disimpulkan bahwa asumsi Matriks kovarians dari semua variabel prediktor relatif sama (equal) terpenuhi.

\subsubsection{Non-Multikolinearitas}

Pada analisis diskriminan asumsi ketiga yang harus terpenuhi adalah Tidak terjadi multikolinearitas (tidak berkorelasi) antar variabel prediktor. Pengujian dilakukan pada semua variabel prediktor yaitu $\mathrm{X}_{1}, \mathrm{X}_{2}$, $\mathrm{X}_{3}, \mathrm{X}_{4}, \mathrm{X}_{5}, \mathrm{X}_{6}$ dan $\mathrm{X}_{7}$ menggunakan nilai VIF. Nilai VIF pada semua variabel prediktor disajikan pada Tabel 4. sebagai berikut:

Tabel 4. Hasi Pengujian Multikolinieritas

\begin{tabular}{ccc}
\hline No. & Variabel Prediktor & Nilai VIF \\
\hline 1. & $\mathrm{X}_{1}$ & 1.010 \\
\hline 2. & $\mathrm{X}_{2}$ & 1.004 \\
\hline 3. & $\mathrm{X}_{3}$ & 1.009 \\
\hline 4. & $\mathrm{X}_{4}$ & 1.009 \\
\hline 5. & $\mathrm{X}_{5}$ & 1.020 \\
\hline 6. & $\mathrm{X}_{6}$ & 1.018 \\
\hline 7. & $\mathrm{X}_{7}$ & 1.015 \\
\hline
\end{tabular}

Berdasarkan nilai VIF pada Tabel 4, diketahui bahwa nilai VIF semua variabel prediktor yaitu $\mathrm{X}_{1}$, $\mathrm{X}_{2}, \mathrm{X}_{3}, \mathrm{X}_{4}, \mathrm{X}_{5}, \mathrm{X}_{6}$ dan $\mathrm{X}_{7}$ lebih kecil dari 5, sehingga dapat disimpulkan bahwa asumsi non multikolinieritas terpenuhi.

\subsection{Analisis Diskriminan}

Hasil jumlah fungsi diskriminan yang terbentuk dapat dilihat pada hasil eigenvalues yang disajikan Tabel 5. sebagai berikut:

Tabel 5. Hasil Fungsi Diskriminan

\begin{tabular}{rrrrr}
\hline Fungsi & Eigenvalue & \% Varian & \% Kumulatif & Canonical Correlation \\
\hline 1 & 0.027 & 100.0 & 100.0 & 0.906 \\
\hline
\end{tabular}

Berdasarkan hasil eigen values pada Tabel 5. diketahui bahwa terbentuk 1 fungsi diskriminan. Peranan fungsi relatif diskriminan juga dapat dilihat pada tabel eigenvalues. Diketahui peranan relatif $Y_{1}$ adalah $100 \%$. Nilai canonical correlation sebesar 0.906 , maka $(0.906)^{2}$ x $100 \%$ adalah $82.08 \%$. Sehingga berdasarkan fungsi diskriminan yang terbentuk, kontribusi pengaruh seluruh variabel prediktor adalah $82.08 \%$.

Selanjutnya berdasarkan hasil analisis diperoleh koefisien diskriminan. Hasil persamaan diskriminan yang terbentuk dapat dilihat pada Canonical Discriminant Function Coefficients yang disajikan pada Tabel 6. sebagai berikut: 
Tabel 6. Hasil Koefisien Diskriminan

\begin{tabular}{cc} 
Variabel & Koefisien \\
\hline $\mathrm{X} 1$ & 0.384 \\
\hline $\mathrm{X} 2$ & 0.057 \\
\hline $\mathrm{X} 3$ & 0.241 \\
\hline $\mathrm{X} 4$ & 0.118 \\
\hline $\mathrm{X} 5$ & 0.029 \\
\hline $\mathrm{X} 6$ & 0.126 \\
\hline $\mathrm{X} 7$ & 0.116 \\
\hline (Constant) & -.451 \\
\hline
\end{tabular}

Berdasarkan hasil Canonical Discriminant Function Coefficients pada Tabel 6, diperoleh persamaan sebagai berikut:

$$
Y=0.451+0.384 X_{1}+0.057 X_{2}+0.241 X_{3}+0.118 X_{4}+0.029 X_{5}+0.126 X_{6}+0.116 X_{7}
$$

Analisis diskriminan bertujuan untuk mengetahui variabel prediktor yang menjadi pembeda terkuat. Fleksibilitas waktu kuliah $\left(\mathrm{X}_{1}\right)$ merupakan variabel dengan koefisien terbesar, hal ini berarti bahwa variabel Fleksibilitas waktu kuliah $\left(\mathrm{X}_{1}\right)$ mempunyai daya pemisah terkuat terhadap kesiapan pembelajaran daring. Hal ini menunjukkan bahwa variabel $\left(\mathrm{X}_{1}\right)$ memberikan penggaruh terbesar pada kesiapan pembelajaran daring di masa pandemi COVID-19. Variabel pembeda terkuat selanjutnya secara berurutan adalah kemudahan pengumpulan tugas $\left(\mathrm{X}_{3}\right)$,pemahaman mahasiswa dalam mengakses e-learning $\left(\mathrm{X}_{6}\right)$, kemudahan interaksi antara dosen dan mahasiswa $\left(\mathrm{X}_{4}\right)$, prasarana untuk kegiatan pembelajaran e-learning mahasiswa $\left(\mathrm{X}_{7}\right)$, kemudahan memahami materi $\left(\mathrm{X}_{2}\right)$, koneksi Internet di tempat mahasiswa menggunakan e-learning $\left(\mathrm{X}_{5}\right)$. Seluruh koefisien dari variabel prediktor bernilai positif yang berarti semakin tinggi nilai koefisien dari variabel prediktor akan berpengaruh terhadap semakin siap mahasiswa melaksanakan pembelajaran daring. Melalui analisis diskriminan juga dapat diketahui prediksi alternatif berdasarkan nilai Classification Function Coefficient disajikan pada Tabel 7, sebagai berikut:

Tabel 7. Hasil Prediksi Alternatif

\begin{tabular}{ccc}
\hline & \multicolumn{2}{c}{ Y } \\
\cline { 2 - 3 } Variabel & $\mathbf{1}$ & $\mathbf{2}$ \\
\hline $\mathrm{X} 1$ & 1.974 & 1.817 \\
\hline $\mathrm{X} 2$ & 1.547 & 1.570 \\
\hline $\mathrm{X} 3$ & 1.293 & 1.194 \\
\hline $\mathrm{X} 4$ & 1.450 & 1.402 \\
\hline $\mathrm{X} 5$ & 1.121 & 1.338 \\
\hline $\mathrm{X} 6$ & 1.636 & 1.584 \\
\hline $\mathrm{X} 7$ & 1.630 & 1.677 \\
\hline (Constant) & 16.684 & 16.918 \\
\hline
\end{tabular}

Berdasarkan hasil Classification Function Coefficient pada Tabel 7, diperoleh persamaan diperoleh persamaan, sebagai berikut:

$$
\begin{aligned}
& Y_{1}=16.684+1.974 X_{1}+1.547 X_{2}+1.293 X_{3}+1.450 X_{4}+1.121 X_{5}+1.636 X_{6}+1.630 X_{7} \\
& Y_{2}=16.918+1.817 X_{1}+1.570 X_{2}+1.194 X_{3}+1.402 X_{4}+1.338 X_{5}+1.584 X_{6}+1.677 X_{7}
\end{aligned}
$$

Apabila nilai $Y_{1}>Y_{2}$ maka dapat dikatakan mahasiswa belum siap dalam menjalani pembelajaran daring. Sebaliknya, apabila $\mathrm{Y}_{1}<\mathrm{Y}_{2}$ maka dapat dikatakan mahasiswa telah siap dalam menjalani pembelajaran daring.

Analisis diskriminan digunakan untuk mengetahui kesiapan mahasiswa terkait pembelajaran daring yang telah dilakukan pada masa pandemi COVID-19. Selain 7 variabel yang berkaitan dengan aspek kesiapan pembelajaran daring beberapa variabel lain yang juga diteliti untuk mengukur kesiapan mahasiswa dalam menjalani pembelajaran daring serta saran kedepan dalam melaksanakan pembelajaran daring dari perspektif 
mahasiswa. Variabel tersebut antara lain adalah media pembelajaran yang memudahkan interaksi dengan dosen $\left(\mathrm{X}_{8}\right)$, media pembelajaran yang memudahkan dalam memahami materi $\left(\mathrm{X}_{9}\right)$ dan sistem pembelajaran yang dipilih saat pandemi berakhir $\left(\mathrm{X}_{10}\right)$.

Tabel 8. Persentase Media Pembelajaran yang Memudahkan Interaksi dengan Dosen

\begin{tabular}{ccc}
\hline No. & $\begin{array}{c}\text { Media Pembelajaran yang Memudahkan } \\
\text { Interaksi dengan Dosen }\end{array}$ & Persentase \\
\hline 1. & Video Conference (Zoom, Google Meet, dsb) & $77.3 \%$ \\
2. & Grup Messanger (Whatsapp atauTelegram) & $16.5 \%$ \\
3. & Fitur Forum Diskusi di E-learning & $6.2 \%$ \\
\hline
\end{tabular}

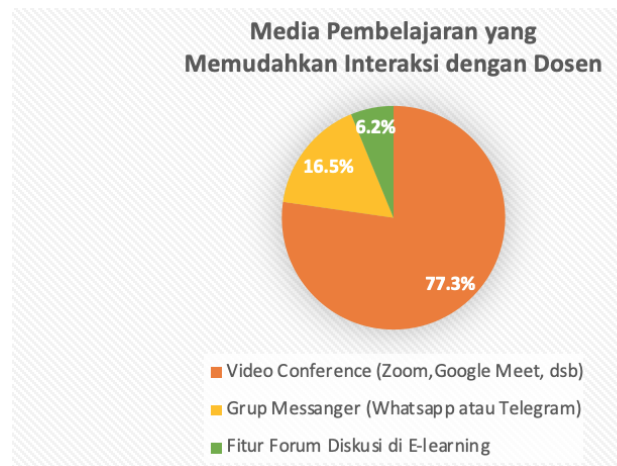

Gambar 1. Persentase Media Pembelajaran yang Memudahkan Interaksi dengan Dosen

Berdasarkan hasil pada Tabel 8 dan Gambar 1 diketahui persentase media pembelajaran yang memudahkan interaksi dengan dosen menurut prespektif mahasiswa. Persentase pilihan media pembelajaran yang digunakan untuk berinteraksi dengan dosen menurut perspektif mahasiswa adalah $77.3 \%$ mahasiswa memilih video conference (Zoom, Google Meet, dsb), $16.5 \%$ mahasiswa memilih grup messanger (Whatsapp atau Telegram) dan $6.2 \%$ memilih fitur forum diskusi di E-learning. Berdasarkan hasil penelitian media pembelajaran yang paling memudahkan interaksi dengan dosen menurut perspektif mahasiswa adalah menggunakan video conference(Zoom, Google Meet, dsb.).

Tabel 9. Persentase Media Pembelajaran yang Memudahkan dalam Memahami Materi

\begin{tabular}{ccc}
\hline No. & $\begin{array}{c}\text { Pilihan Media Pembelajaran yang Memudahkan } \\
\text { dalam Memahami Materi }\end{array}$ & Persentase \\
\hline 1. & Video Conference (Zoom, Google Meet, dsb) & $35.2 \%$ \\
\hline 2. & Video Pembelajaran (Youtube, dsb) & $32.8 \%$ \\
\hline 3. & Fitur Forum Diskusi di E-learning & $15.6 \%$ \\
\hline 4. & Materi dari Dosen (ppt, pdf, dsb) & $16.4 \%$ \\
\hline
\end{tabular}




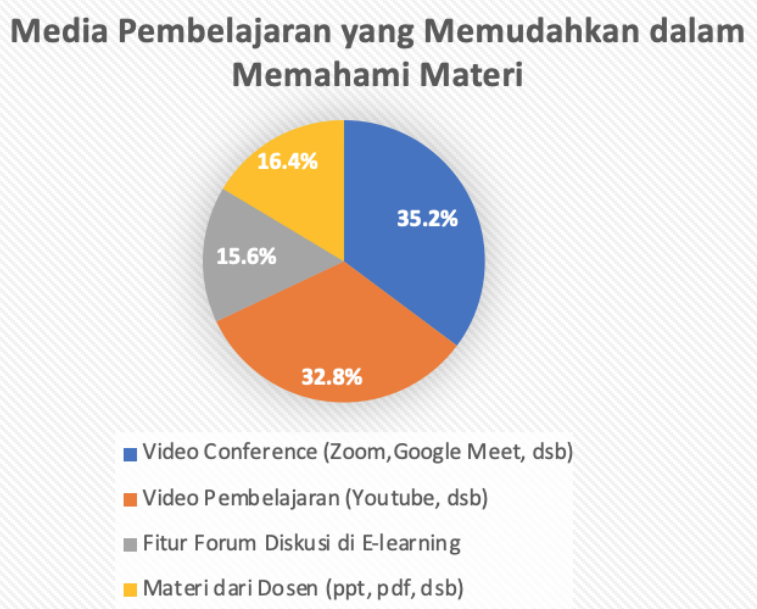

Gambar 2. Persentase Media Pembelajaran yang Memudahkan dalam Memahami Materi

Berdasarkan hasil pada Tabel 9 dan Gambar 2 diketahui persentase media pembelajaran yang memudahkan dalam memahami materi menurut prespektif mahasiswa. Persentase pilihan media pembelajaran yang memudahkan dalam memahami materi menurut perspektif mahasiswa adalah $35.2 \%$ mahasiswa memilih video conference (Zoom, Google Meet, dsb), 32.8\% mahasiswa memilih video pembelajaran (Youtube,dsb), 15.6\% memilih fitur forum diskusi di E-learning dan $16.4 \%$ memilih materi dari dosen (ppt,pdf, dsb). Berdasarkan hasil penelitian media pembelajaran yang paling memudahkan dalam memahami materi menurut perspektif mahasiswa adalah menggunakan video conference (Zoom, Google Meet, dsb) dan video pembelajaran (Youtube,dsb.).

Tabel 10. Sistem Pembelajaran yang Dipilih Saat Pandemi Berakhir

\begin{tabular}{ccc}
\hline No. & $\begin{array}{c}\text { Sistem Pembelajaran yang Dipilih Saat Pandemi } \\
\text { Berakhir }\end{array}$ & Persentase \\
\hline 1 & Sistem Daring 100\% & $1.60 \%$ \\
\hline 2 & Sistem daring 70 \% dan luring 30\% & $7.80 \%$ \\
\hline 3 & Sistem daring 50 \% dan luring50\% & $25 \%$ \\
\hline 4 & Sistem daring 30\% dan luring $70 \%$ & $38.30 \%$ \\
\hline 5 & Sistem Luring 100 \% & $27.30 \%$ \\
\hline
\end{tabular}

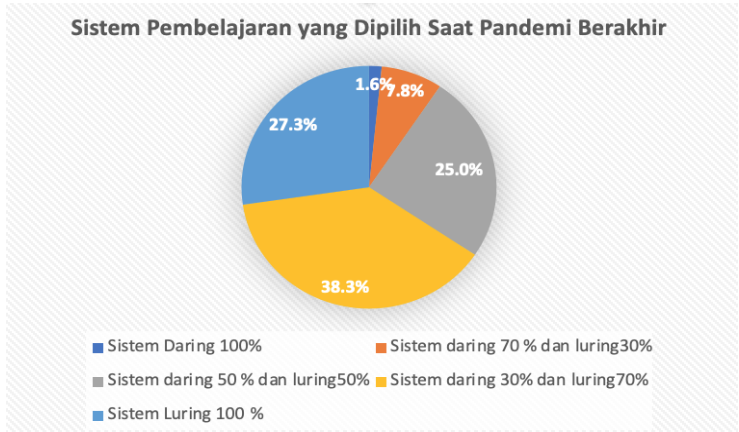

Gambar 3. Sistem Pembelajaran yang Dipilih Saat Pandemi Berakhir

Berdasarkan hasil pada Tabel 10 dan Gambar 3 diketahui persentase sistem pembelajaran yang dipilih mahasiswa saat pandemi COVID-19 berakhir. Persentase pilihan sistem pembelajaran menurut perspektif mahasiswa adalah 38.3\% mahasiswa memilih sistem daring 30\% dan luring 70\%, $27.3 \%$ mahasiswa memilih luring $100 \%, 25 \%$ memilih daring 50\% dan luring 50\%, $7.8 \%$ mahasiswa memilih daring $70 \%$ dan luring $30 \%$, dan $1.6 \%$ memilih daring $100 \%$. Berdasarkan hasil penelitian sistem pembelajaran yang paling dipilih oleh mahasiswa saat pandemi COVID-19 berakhir adalah sistem daring 30\% dan luring 70\%. 


\section{KESIMPULAN}

Berdasarkan hasil penelitian kesimpulan yang didapatkan adalah variabel prediktor yang menjadi pembeda terkuat adalah fleksibilitas waktu kuliah $\left(\mathrm{X}_{1}\right)$ karena merupakan variabel dengan koefisien terbesar. Hal ini berarti bahwa variabel fleksibilitas waktu kuliah $\left(\mathrm{X}_{1}\right)$ mempunyai daya pemisah terkuat terhadap kesiapan pembelajaran daring di masa pandemi COVID-19. Selain itu berdasarkan hasil penelitian juga diketahui bahwa menurut perspektif mahasiswa, media pembelajaran yang paling memudahkan interaksi dengan dosen adalah menggunakan video conference (Zoom, Google Meet, dsb) serta media pembelajaran yang paling memudahkan dalam memahami materi adalah menggunakan video conference (Zoom, Google Meet, dsb). Disisi lain pilihan sistem pembelajaran yang paling dipilih oleh mahasiswa saat pandemi COVID19 berakhir adalah sistem daring 30\% dan luring 70\%.

\section{DAFTAR PUSTAKA}

[1] Y. D. Cahyono, "E-learning (Edmodo) Sebagai Media Pembelajaran Sejarah,” J. Penelit., vol. 18, no. 2, pp. 102-112, 2015.

[2] Rusman, Seri Manajemen Sekolah Bermutu: Model-Model Pembelajaran Mengembangkan Profesionalitas Guru. Jakarta: PT Raja Grafindo Persada, 2012.

[3] A. Sadikin and A. Hamidah, "Pembelajaran Daring di Tengah Wabah Covid-19," BIODIK, vol. 6, no. 2, pp. 109-119, Jun 2020, doi: 10.22437/bio.v6i2.9759.

[4] O. I. Handarini and S. S. Wulandari, "Pembelajaran Daring Sebagai Upaya Study From Home (SFH) Selama Pandemi Covid 19," J. Pendidik. Adm. Perkantoran, vol. 8, no. 3, pp. 496-503, 2020.

[5] H. Putria, L. H. Maulana, and D. A. Uswatun, "Analisis Proses Pembelajaran Dalam Jaringan (DARING) Masa Pandemi COVID-19 pada Guru Sekolah Dasar,” J. basicedu, vol. 4, no. 2, pp. 861-872, 2020, doi: 10.31004/basicedu.v4i4.445.

[6] W. A. F. Dewi, "Dampak COVID-19 terhadap Implementasi Pembelajaran Daring di Sekolah Dasar,” Edukatif J. Ilmu Pendidik., vol. 2, no. 1, pp. 55-61, 2020, doi: 10.31004/edukatif.v2i1.89.

[7] J. Hair, W. Black, B. Babin, and R. Anderson, Multivariate Data Analysis, 8 th Editi. New Jersey: Prentice-Hall, 2010.

[8] E. W. Thomas, M. J. Marr, A. Thomas, R. M. Hume, and N. Walker, "Using discriminant analysis to identify students at risk," Proc. - Front. Educ. Conf., no. March 2014, pp. 185-188, 1996, doi: 10.1109/fie.1996.569940.

[9] M. J. Alrawashdeh, T. R. Radwan, and K. A. Abunawas, "Performance of Linear Discriminant Analysis Using Different Robust Methods," Eur. J. Pure Appl. Math., vol. 11, no. 1, p. 284, 2018, doi: 10.29020/nybg.ejpam.v11i1.3176.

[10] A. H. Blasi, “Applications of Discriminant Analysis,” no. January, 2020.

[11] S. Ayinla and B. Kehinde Adekunle, “An Overview and Application of Discriminant Analysis in Data Analysis,” IOSR J. Math., vol. 11, no. 1, pp. 2278-5728, 2015, doi: 10.9790/5728-11151215.

[12] H. Bakari, A. Isa, and U. Zannah, "Application of Discriminant Analysis in Modelling Students'Placement in Colleges of Education," vol. 52, no. 249, 2015.

[13] A. Tharwat, T. Gaber, A. Ibrahim, and A. E. Hassanien, "Linear discriminant analysis: A detailed tutorial," AI Commun., vol. 30, no. 2, pp. 169-190, 2017, doi: 10.3233/AIC-170729.

[14] N. A. A. Shashoa, N. A. Salem, I. N. Jleta, and O. Abusaeeda, "Classification depend on linear discriminant analysis using desired outputs," 2016 17th Int. Conf. Sci. Tech. Autom. Control Comput. Eng. STA 2016 - Proc., no. December 2016, pp. 328-332, 2017, doi: 10.1109/STA.2016.7952041.

[15] R. J. Iskandar, "Penerapan Alggoritma Linear Discriminant Analysis (LDA) untuk Pengenalan Wajah Sebagai Pemantau Kehadiran Karyawan," vol. IX, no. 01, 2013. 